๑๐. В. Кліщ, Г. А. Павлишин

ДВНЗ «Тернопільсъкий державний медичний університет ілені І. Я. Горбачевсъкого МОЗ України»

\title{
ХАРАКТЕРИСТИКА ДІЯЛЬНОСТІ НЕОНАТОЛОГІЧНОЇ СЛУЖБИ РІВНЕНСЬКОГО ОБЛАСНОГО ПЕРИНАТАЛЬНОГО ЦЕНТРУ
}

Мета дослідження - оцінити основні показники діяльності неонатологічної служби Рівненського обласного перинатального центру впродовж останніх років.

Матеріали та методи. Проведено ретроспективний статистичний аналіз динаміки основних показників роботи відділення інтенсивної терапії новонароджених Рівненського обласного перинатального центру, таких, як народжуваність, захворюваність, неонатальна смертність, за період 2016-2018 рр.

Результати дослідження та їх обговорення. Аналіз народжуваності в Рівненському обласному перинатальному центрі свідчить про зниження її рівня в області, при цьому кількість передчасно народжених дітей не зменшується, становлячи 8,7-8,9 \%. Показники неонатальної смертності як в області, так і в перинатальному центрі знижуються. У структурі смертності переважають гіпоксично-ішемічні ураження нервової системи, уроджені вади розвитку, внутрішньоутробні інфекції, глибока морфоорункціональна незрілість. Уроджені вади серця, не сумісні з життям або в поєднанні з множинними вадами розвитку, переважають у структурі смертності від уроджених вад розвитку. В Рівненському обласному перинатальному центрі рівень виживання немовлят, народжених з екстремально малою масою тіла, має стабільну тенденцію до збільшення - від 25 \% у 2016 р. до 40 \% у 2018 р. У структурі захворюваності переважають неонатальна енцефалопатія, уроджені вади розвитку, інсекційна патологія.

Висновок. Оцінка основних показників роботи неонатологічної служби Рівненського обласного перинатального центру впродовж останніх років розкриває переваги і труднощі в діяльності неонатологічної служби в області.

Ключові слова: новонароджені; передчасно народжені; народжуваність; неонатальна смертність; захворюваність; рівень виживання.

ХАРАКТЕРИСТИКА ДЕЯТЕЛЬНОСТИ НЕОНАТОЛОГИЧЕСКОЙ СЛУЖБЫ РОВЕНСКОГО ОБЛАСТНОГО ПЕРИНАТАЛЬНОГО ЦЕНТРА

Цель исследования - оценить основные показатели деятельности неонатологической службы Ровенского областного перинатального центра в течение последних лет.

Материалы и методы. Проведен ретроспективный статистический анализ динамики основных показателей работы отделения интенсивной терапии новорожденных Ровенского областного перинатального центра, таких, как рождаемость, заболеваемость, неонатальная смертность, за период 2016-2018 гг.

Результаты исследования и их обсуждение. Анализ рождаемости в Ровенском областном перинатальном центре свидетельствует о снижении ее уровня в области, при этом количество преждевременно рожденных детей не уменьшается, составляя 8,7-8,9\%. Показатели неонатальной смертности как в области, так и в перинатальном центре снижаются. В структуре смертности преобладают гипоксически-ишемические поражения нервной системы, врожденные пороки развития, внутриутробные инорекции, глубокая морфоорункциональная незрелость. Врожденные пороки сердца, не совместимые с жизнью или в сочетании с множественными пороками развития, преобладают в структуре смертности от врожденных пороков развития. В Ровенском областном перинатальном центре уровень выживания младенцев, рожденных с экстремально низкой массой тела, имеет стабильную тенденцию к увеличению - от 25 \% в 2016 г. до 40 \% в 2018 г. В структуре заболеваемости преобладают неонатальная энцефалопатия, врожденные пороки развития, инфекционная патология.

Вывод. Оценка основных показателей работы неонатологической службы Ровенского областного перинатального центра в течение последних лет раскрывает преимущества и трудности в деятельности неонатологической службы области.

Ключевые слова: новорожденные; преждевременно рожденные; рождаемость; неонатальная смертность; заболеваемость; уровень выживания.

CHARACTERISTICS OF OPERATION OF THE NEONATOLOGICAL SERVICE IN THE RIVNE REGIONAL PERINATAL CENTER

The aim of the study - to assess the main indicators of the neonatal service of the Rivne Regional Perinatal Center during recent years.

Materials and Methods. A retrospective statistical analysis of the dynamics of the main indicators of Department of Intensive Care of Newborns of the Rivne Regional Perinatal Center - fertility, morbidity, neonatal mortality for the period 2016-2018 years was carried out.

Rresults and Discussion. The analysis of fertility in the Rivne Regional Perinatal Center shows a decrease in the birth rate in the region, while the number of premature infants does not decrease, amounting to 8.7-8.9\%. Indicators of neonatal mortality in the region and in the perinatal center are reduced. In the structure of death mortality is dominated by hypoxic-ischemic disorders of the nervous system, congenital malformations, intrauterine infections, deep morpho-functional immaturity. Congenital heart defects that are incompatible with life or in combination with multiple birth defects prevail in the structure of congenital malformations. In the Rivne Perinatal Center, the survival rate of preterm infants with an extremely low birth weight has a stable tendency to increase from $25 \%$ in 2016 to $40 \%$ in 2018. The structure of the disease is dominated by neonatal encephalopathy, congenital malformation, infectious pathology.

Conclusion. The evaluation of the main neonatal indicators of the Rivne Regional Perinatal Center during the last years reveals the advantages and difficulties in the activity of the neonatal service of the region.

Key words: newborns; premature births; fertility; neonatal mortality; morbidity; survival rate. 
ВСтУП. На сьогодні кількість передчасно народжених дітей зростає в усьому світі. Так, за даними ВОО3, щороку близько 15 млн дітей народжуються передчасно, це більше однієї дитини з десяти [1, 2]. У 184 країнах показник передчасних пологів коливається від 5 до $18 \%$ від числа усіх народжених дітей, понад 60 \% передчасних пологів відбуваються в Африці та Південній Азії. До країн з найбільшою кількістю передчасних пологів належать: Індія, Китай, Нігерія, Пакистан, Індонезія, США, Бангладеш, Філіппіни, Демократична Республіка Конго, Бразилія [1, $3,4]$. В Україні цей показник становить близько 5,8 \%. Так, за даними центру медичної статистики МОЗ України, щороку передчасно народжується до 20000 малюків, близько 2000 з них - з дуже малою масою тіла, до 1000 немовлят - $з$ екстремально малою масою тіла [5].

У всьому світі недоношеність $є$ провідною причиною смерті дітей віком до 5 років. щороку близько 1 млн дітей помирає від ускладнень, пов'язаних з недоношеністю. Водночас багато передчасно народжених дітей стикається з розвитком хронічної патології, інвалідністю, проблемами зору, слуху, мовного розвитку, а в подальшому - $з$ труднощами у навчанні, синдромом шкільної дизадаптації, розладами емоційної ссрери, регуляторними порушеннями [5-8]. Однак досягнення перинатальної та неонатальної інтенсивної терапії, створення перинатальних центрів III рівня з наданням висококваліфрікованої медичної допомоги сприяють покращенню виживання недоношених дітей з екстремально малою і дуже малою масою тіла. На сьогодні в більшості областей України вже функціонують високоспеціалізовані перинатальні центри, які забезпечено сучасним медичним обладнанням, інноваційними технологіями, кваліфікованим медичним персоналом [9]. Одним із таких закладів $є$ Рівненський обласний перинатальний центр (ОПЦ), який надає висококваліфіковану медичну допомогу вагітним і новонародженим в області та за ії межами. Оцінка народжуваності, перинатальної та неонатальної смертності $€$ важливим медико-демографічним показником, що об'єктивно відображає стан здоров'я та якість надання медичної допомоги дітям, а також рівень соціально-економічного розвитку регіону.
МЕТА ДОСЛІДЖЕННЯ - оцінити діяльність неонатологічної служби Рівненського обласного перинатального центру на основі аналізу динаміки основних показників роботи відділення інтенсивної терапії впродовж останніх років та 3'ясувати можливості покращення надання медичної допомоги новонародженим.

МАТЕРІАЛИ ТА МЕТОДИ. У ході дослідження проведено ретроспективний статистичний аналіз динаміки основних показників роботи відділення інтенсивної терапії новонароджених Рівненського обласного перинатального центру, таких, як рівень народжуваності, захворюваності, нозологічна, вікова структура втрат новонароджених, динаміка показників ранньої неонатальної та неонатальної смертності, за період 2016-2018 рр. Статистичну обробку отриманих результатів проводили за допомогою програми Statistica 6.0. Excel для Windows.

РЕЗУЛЬТАТИ ДОСЛІДЖЕННЯ ТА ЇХ ОБГОВОРЕННЯ. Основні показники неонатологічної служби Рівненського обласного перинатального центру свідчать про негативну тенденцію щодо народжуваності. Так, у Рівненському ОПЦ упродовж 2016-2018 рр. відбулося 9955 пологів, зокрема, у 2016 р. - 3751, у 2017 р. - 3244, у 2018 р. 2960, що свідчить про зниження рівня народжуваності в області, як і в Україні загалом (табл. 1).

Незважаючи на таку негативну тенденцію щодо народжуваності, кількість передчасно народжених дітей не зменшується, становлячи в середньому 8,7-8,9 \% (табл. 2). Так, у 2016 р. передчасно народилось 308 немовлят, у 2017 р. - 274, у 2018 р. - 228, з них 19-20\% дітей з дуже малою та екстремально малою масою тіла при народженні (рис. 1).

Варто відзначити, що екстремально недоношені діти в Рівненській області здебільшого концентруються в обласному перинатальному центрі (табл. 3), де створено всі умови для такої категорії пацієнтів.

Аналіз показників роботи відділення інтенсивної терапії новонароджених Рівненського ОПЦ свідчить про тенденцію до щорічного зниження кількості госпіталізованих новонароджених, як доношених з тяжкою перинатальною патологією, так і передчасно народжених, що, очевидно,

Таблиця 1. Рівень народжуваності в Рівненському регіоні

\begin{tabular}{|c|c|c|c|}
\hline Рік & Рівненська область & Рівненський ОПЦ & Україна \\
\hline 2016 & 15688 & 3784 & 379098 \\
\hline 2017 & 14371 & 3301 & 347835 \\
\hline 2018 & 13380 & 2999 & 325887 \\
\hline
\end{tabular}

Таблиця 2. Показники народжуваності в Рівненському обласному перинатальному центрі впродовж $2016-2018$ рр.

\begin{tabular}{|l|c|c|c||}
\hline \multicolumn{1}{|c|}{ Показник } & \multicolumn{2}{c|}{ Рік } \\
\cline { 2 - 4 } & 2016 & 2017 & 2018 \\
\hline Усього новонароджених & 3784 & 3301 & 2999 \\
\hline Доношені новонароджені & 3476 & 3027 & 2771 \\
\hline Передчасно народжені & 308 & 274 & 228 \\
\hline 3а ваговими категоріями: & & & \\
500-999 г & 29 & 24 & 29 \\
$1000-1499$ г & 33 & 29 & 46 \\
$1500-1999$ г & 55 & 83 & 64 \\
2000-2499 г & 91 & 64 & 58 \\
$2500-2999$ г & 71 & & \\
\hline
\end{tabular}




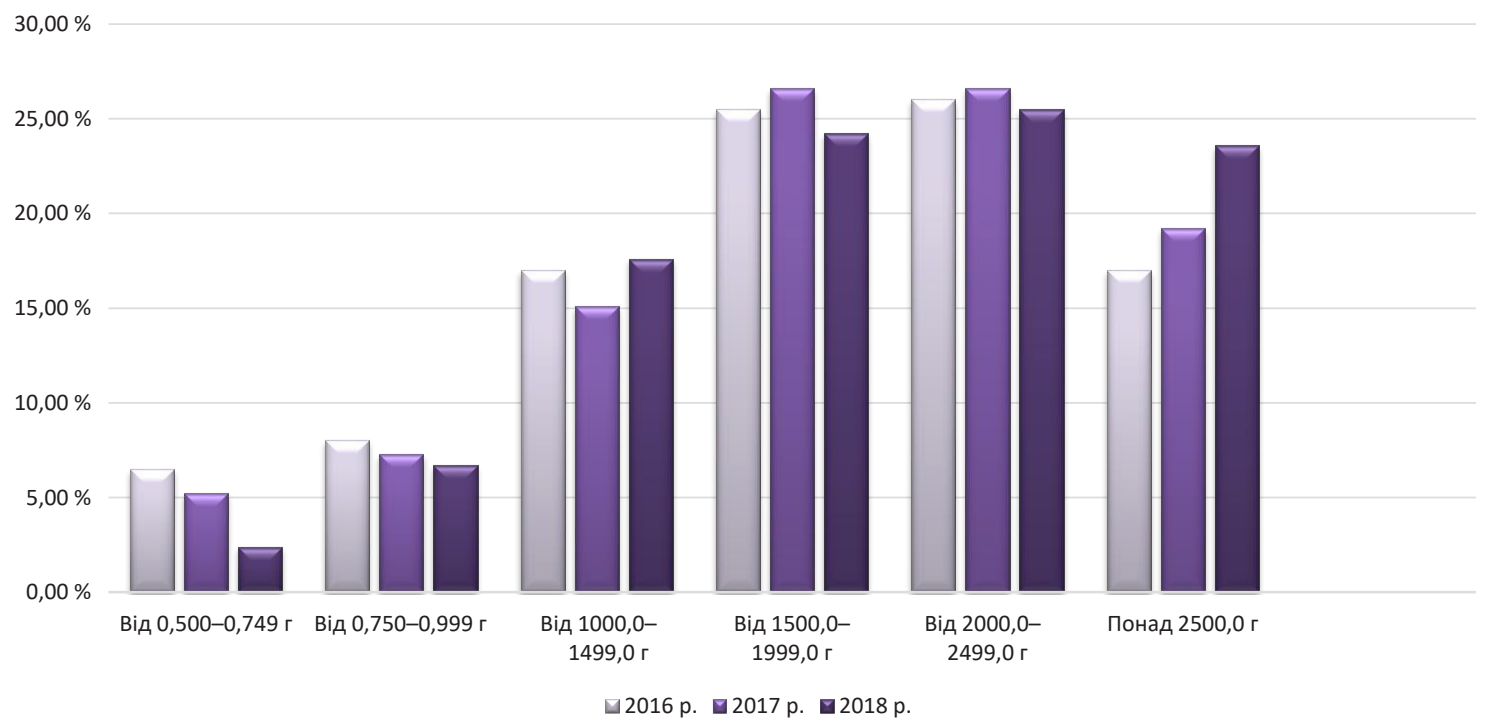

Рис. 1. Вагова крива передчасно народжених немовлят у Рівненському обласному перинатальному центрі.

Таблиця 3. Показники народжуваності екстремально недоношених дітей у Рівненській області

\begin{tabular}{|l|c|c|c|}
\hline Рік & 2016 & 2017 & 2018 \\
\hline Рівненська область & 44 & 42 & 33 \\
\hline Рівненський обласний перинатальний центр & 29 & 24 & 15 \\
\hline
\end{tabular}

пов'язано як із зменшенням народжуваності, так і з ефективністю надання медичної допомоги вагітним (табл. 4).

Варто зазначити, що частка передчасно народжених дітей, які потребували лікування у відділенні інтенсивної терапії новонароджених, у 2016 р. становила 60 \%, у 2017 p. $-66 \%$, у 2018 p. $-63 \%$.

Оцінка статистичних показників, які відображають якість надання допомоги матерям та новонародженим упродовж
2016-2018 рр., підтверджує позитивну тенденцію щодо зниження показників неонатальної смертності. Показники неонатальної смертності в Рівненському ОПЦ перевищують показники неонатальної смертності по Рівненській області, що зумовлено концентрацією тяжкої перинатальної патології в обласному перинатальному центрі (табл. 5).

Водночас нестабільні коливання показників ранньої неонатальної смертності підтверджують недоліки як в

Таблиця 4. Показники роботи відділення інтенсивної терапії новонароджених Рівненського обласного перинатального центру впродовж 2016-2018 рр.

\begin{tabular}{|c|c|c|c|}
\hline \multirow{2}{*}{ Показник } & \multicolumn{3}{|c|}{ Рік } \\
\hline & 2016 & 2017 & 2018 \\
\hline $\begin{array}{l}\text { Діти, госпіталізовані у відділення інтенсивної } \\
\text { терапії новонароджених }\end{array}$ & 325 & 290 & 265 \\
\hline Доношені діти & 128 & 98 & 99 \\
\hline Передчасно народжені діти & 197 & 192 & 166 \\
\hline \begin{tabular}{|c|} 
Померли: \\
3 них недоношені діти \\
до 500 г \\
$500-999$ г \\
$1000-1499$ г \\
$1500-1999$ г \\
$2000-2499$ г \\
$2500-2999$ г
\end{tabular} & $\begin{array}{l}34 \\
25 \\
- \\
19 \\
3 \\
2 \\
1 \\
-\end{array}$ & $\begin{array}{c}33 \\
32 \\
- \\
18 \\
7 \\
4 \\
1 \\
2\end{array}$ & $\begin{array}{l}24 \\
18 \\
- \\
8 \\
7 \\
1 \\
1 \\
1\end{array}$ \\
\hline
\end{tabular}

Таблиця 5. Динаміка показників неонатальної смертності в Рівненському регіоні (на 1000 народжених)

\begin{tabular}{|c|c|c|c|c|c|c|}
\hline \multirow{3}{*}{ Показник } & \multicolumn{3}{|c|}{ Рівненський ОПЦ } & \multicolumn{3}{|c|}{ Рівненська область } \\
\hline & \multicolumn{6}{|c|}{ рік } \\
\hline & 2016 & 2017 & 2018 & 2016 & 2017 & 2018 \\
\hline Рання неонатальна смертність, \%о & 6,6 & 6,0 & 6,3 & 3,5 & 3,7 & 3,0 \\
\hline Неонатальна смертність, \%о & 8,9 & 8,7 & 8,0 & 5,0 & 5,8 & 4,4 \\
\hline
\end{tabular}


акушерській службі (спостереження за жінкою під час вагітності, пологів), так і в наданні неонатологічної допомоги. Зважаючи на це, потенціал зниження цих показників визначається станом здоров'я жінки до і під час вагітності, вдосконаленням пренатальної діагностики, якістю та своєчасністю надання медичних послуг матері й новонародженому.

Серед причин смерті новонароджених основними були гіпоксично-ішемічні ураження нервової системи, уроджені вади розвитку, глибока морфофункціональна незрілість, внутрішньоутробні інфекції. Так, у структурі неонатальної смертності передчасно народжених дітей у період з 2016 до 2018 р. I місце займали гіпоксично-ішемічні ураження нервової системи, внутрішньошлуночкові крововиливи, 3 яких 54 \% - крововиливи III- IV ступенів (табл. 6). У структурі смертності від уроджених вад розвитку чільне місце посідали уроджені вади серця, не сумісні з життям або в поєднанні з множинними вадами розвитку.

Одним із важливих показників якості роботи відділення інтенсивної терапії новонароджених Рівненського обласного перинатального центру є рівень виживання передчасно народжених дітей за ваговими кривими (рис. 2).

Аналіз показників виживання немовлят, народжених 3 екстремально малою масою тіла у відділенні інтенсивної терапії Рівненського обласного перинатального центру, засвідчив якість надання допомоги найменшим пацієнтам. Так, у 2016 р. цей показник становив $25 \%$, у 2017 р. - 30 \%, у 2018 р. - 40 \%, тобто має стабільну тенденцію до зростання, однак, порівняно з високорозвиненими країнами, залишається ще надто низьким.

У структурі захворюваності відділення інтенсивної терапії новонароджених Рівненського обласного перинатального центру впродовж 2016-2018 рр. чільне місце посідали неонатальна енцефалопатія, уроджені вади розвитку та інфрекційна патологія (табл. 7). Особливої уваги потребує питання щодо зростання гнійно-септичних захворювань серед пацієнтів відділення інтенсивної терапії новонароджених з переважанням у передчасно народжених дітей.

Серед уроджених вад розвитку домінували уроджені вади серця, особливо в передчасно народжених немовлят, зокрема, у 2016 р. - 47,6 \% випадків, у 2017 р. - 36,4 \%, у 2018 р. - 35,3 \%. Вади шлунково-кишкового тракту і сечостатевої системи посідали II місце, а саме у 2016 р. - в 14,2 \% дітей, у 2017 р. - у 22,7 \%, у 2018 р. -у 29,4 \%, що свідчить про необхідність покращити якість пренатальної діагностики в області.

Таблиця 6. Структура неонатальної смертності передчасно народжених дітей у Рівненському обласному перинатальному центрі

\begin{tabular}{|c|c|c|c|}
\hline \multirow{2}{*}{$\begin{array}{l}\text { Струк- } \\
\text { тура }\end{array}$} & \multicolumn{3}{|c|}{ Причини смерті } \\
\hline & 2016 p. & 2017 p. & 2018 p. \\
\hline I місце & Гіпоксично-ішемічне ураження ЦНС & Внутрішньоутробна інфекція & Гіпоксично-ішемічне ураження ЦНС \\
\hline II місце & $\begin{array}{l}\text { Глибока морфофуункціональна } \\
\text { незрілість }\end{array}$ & Гіпоксично-ішемічне ураження ЦНС & $\begin{array}{l}\text { Глибока морфофуункціональна } \\
\text { незрілість }\end{array}$ \\
\hline III місце & Уроджені вади розвитку & $\begin{array}{l}\text { Глибока морфофункціональна } \\
\text { незрілість }\end{array}$ & Внутрішньоутробна інфекція \\
\hline
\end{tabular}

$$
2016 \text { p. } 2017 \text { p. } 2018 \text { p. }
$$

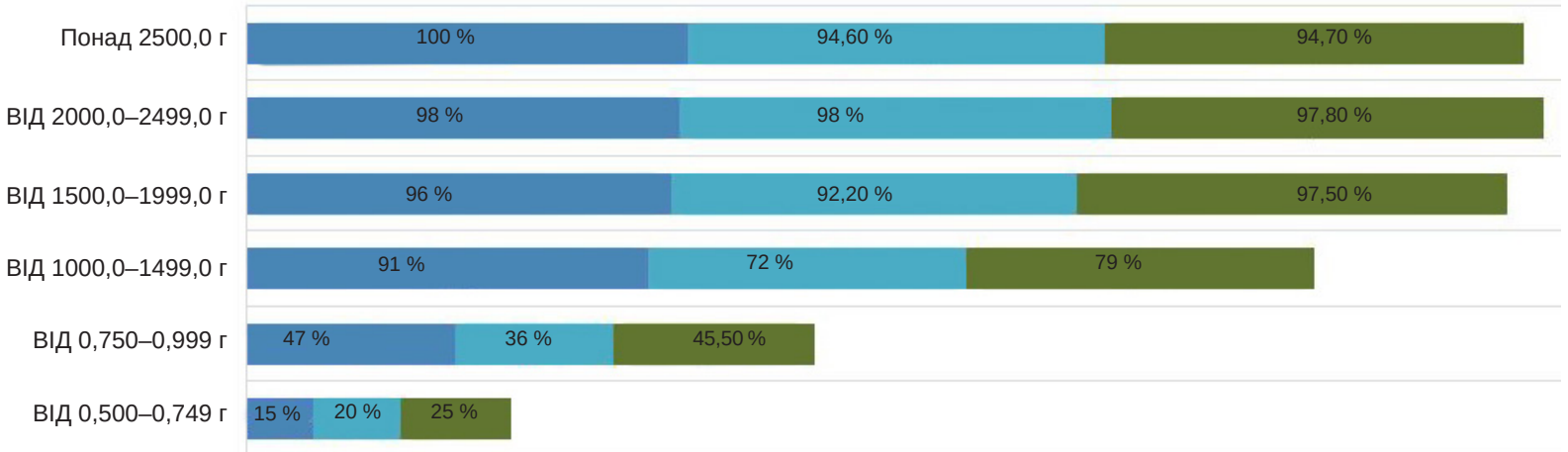

Рис. 2. Рівень виживання передчасно народжених дітей у Рівненському обласному перинатальному центрі.

Таблиця 7. Структура захворюваності відділення інтенсивної терапії новонароджених Рівненського обласного перинатального центру

\begin{tabular}{|l|c|c|c|}
\hline \multicolumn{2}{|c|}{ Нозологія } & \multicolumn{3}{c|}{ Рік } & 2018 \\
\cline { 2 - 4 } & 2016 & 2017 & 66,8 \\
\hline Неонатальна енцесралопатія, \% & 47,6 & 50,0 & 12,6 \\
\hline Респіраторний дистрес-синдром, \% & 7,2 & 9,3 & 30,7 \\
\hline Гнійно-септичні захворювання, \% & 8,2 & 18,7 & 12,5 \\
\hline Уроджені вади розвитку, \% & 10,7 & 13,1 & 10,3 \\
\hline Інші, \% & 10,7 & 11,4 & \\
\hline
\end{tabular}


Висновки. Зважаючи на викладене вище, в Рівненському регіоні впродовж років спостерігають стійку тенденцію до зниження народжуваності, зменшення кількості новонароджених, однак стабільний показник відносно передчасно народжених немовлят коливається в межах 8,7-8,9 \%. При цьому покращились показники виживання передчасно народжених немовлят, особливо з групи екстремально недоношених, знизились показники неонатальної смертності, що свідчить про вдосконалення неонатологічної допомоги, включаючи своєчасну й ефективну інтенсивну терапію новонароджених, упровадження інноваційних технологій. У структурі неонатальної смертності домінують втрати новонароджених з дуже малою та екстремально малою масою тіла, в нозологічній структурі залишаються високими втрати дітей від уроджених вад розвитку, що

\section{СПИСОК ЛІТЕРАТУРИ}

1. WHO. Preterm birth. URL : https://www.who.int/newsroom/fact-sheets/detail/preterm-birth

2. Global, regional, and national causes of under-5 mortality in 2000-15: an updated systematic analysis with implications for the sustainable development goals / L. Liu, S. Oza, D. Hogan [et al.] // Lancet. - 2016. - No. 388 (10063). - P. 3027-3035.

3. Barros F. C. Global report on preterm birth and stillbirth: evidence for effectiveness of interventions / F. C. Barros, Z. qar Ahmed Bhutta, M. Batra // BMC Pregnancy and Childbirth. 2010. - Vol. 10. - P. 303-357.

4. Передчасно народжені діти: сучасний погляд на постнатальну адаптацію та стан здоров'я у ранньому віці / В. І. Похилько, Г. М.Траверсе, С. М. Цвіренко [та ін.] // Вісн. проблем біології і медицини. -2016. - Вип. 1, т. 2, № 127. - С. 23-27.

5. Моніторинг стану здоров'я матері та дитини (MATRIX - BABIES) : аналітично-статистистичний довідник. - 2018.

6 . Vanden Berg. Neurodevelopment of preterm infants at 24 months after neonatal supplementation of aprebiotic mix: потребує вдосконалення пренатальної діагностики, впровадження перинатального аудиту плода, підвищення якості послуг з контрацепції, що дасть змогу зменшити ймовірність народження дітей з уродженими вадами розвитку. Водночас зростання інфрекційної патології серед передчасно народжених дітей відділення інтенсивної терапії свідчить про високий ризик виникнення нозокоміальної інфрекції, що потребує посилення інфекційного контролю у відділенні.

ПЕРСПЕКТИВИ ПОДАЛЬШИХ ДОСЛІДЖЕНЬ. ПОдальші дослідження варто спрямувати на більш детальне вивчення віддаленого катамнезу новонароджених, особливо передчасно народжених, які перебували на лікуванні у відділенні інтенсивної терапії новонароджених Рівненського обласного перинатального центру, та на порівняння показників України та Європи.

A randomized trial // J. P. Van den Berg, E. A. Westerbeek, T. J. Bröring-Starre // Pediatr. Gastroenterol. Nutr. - 2016. No. 63 (2). - P. 270-276// doi: 10.1097/ MPG 00000000001148.

7. Browne J. V. Developmental supports for newborns and young infants with special health and developmental needs and their families: The BABIES Model / J. V. Browne, A. Talmi. - URL : http://wonderbabies.org/wp-content/uploads/2016/03/ Dev_-Supports-for-Newborns-Young-Infants-withSpecial-Health-Dev_-Needs-Their-Families-The-BABIESModel.pdf

8. Altimier L. The neonatal integrative developmental care model: Seven neuroprotective core measures for family-centered developmental care / L. Altimier, R. Phillips // Newborn \& Infant Nursing. - 2013. - No. 13 (1). - P. 9-22.

9. Аналіз роботи перинатальних центрів у виходжуванні передчасно народжених дітей в Україні / Т. К. Знаменська, Л. І. Нікуліна, Н. Г. Руденко, О.В.Воробйова // Неонатологія, хірургія, перинатальна медицина. -2017. - № 2 (24). - С. 5-7.

\section{REFERENCES}

1. WHO. Preterm birth. Retrieved from: https://www.who.int/ news-room/fact-sheets/detail/preterm-birth

2. Liu, L., Oza, S., Hogan, D., Chu, Y., Perin, J., Zhu, J., et al. (2016). Global, regional, and national causes of under-5 mortality in 2000-15: an updated systematic analysis with implications for the sustainable sevelopment goals. Lancet, 388 (10063), 3027-3035.

3. Barros, F.C., qar Ahmed Bhutta, Z., \& Batra, M. (2010). Global report on preterm birth and stillbirth: evidence for effectiveness of interventions. BMC Pregnancy and Childbirth, 10, 303-357.

4. Pokhylko, V.I., Traverse, H.M., Tsvirenko, S.M., Zhuk, L.A., \& Oskomenko, M. M. (2016). Peredchasno narodzeni dity: suchasnyi pohliad na postnatalnu adaptatsiiu ta stan zdroviia $v$ ranniomu vitsi [Prematurely born children: A modern view of postnatal adaptation and early childhood health]. Visnyk problem biolohii i medytsyny - Bulletin of Problems of Biology and Medicine, 1 (2) 127, 23-27 [in Ukrainian].

5. (2018). Analitichno-statistychnyi dovidnyk "Monitorynh stanu zdorovia materi ta dytyny (MATRIX - BABIES)" [Analytical and statistical guide "Monitoring of the health of mother and child (MATRIX - BABIES)"]. [in Ukrainian].
6. Van den Berg, J.P., Westerbeek, E.A., Bröring-Starre, T., Garssen, J., van Elburg, R.M. (2016). Neurodevelopment of preterm infants at 24 months after neonatal supplementation of aprebiotic Mix: A randomized trial. J. Pediatr. Gastroenterol. Nutr., 63 (2), 270-276. doi: 10.1097/ MPG 00000000001148.

7. Browne, J.V., \& Talmi, A. (2012). Developmental supports for newborns and young infants with special health and developmental needs and their families: The BABIES Model. Retrieved from: http://wonderbabies.org/wp-content/uploads/2016/03/ Dev_-Supports-for-Newborns-Young-Infants-with-SpecialHealth-Dev -Needs-Their-Families-The-BABIES-Model.pdf

8. Altimier, L., \& Phillips, R. (2013). The neonatal integrative developmental care model: Seven neuroprotective core measures for family-centered developmental care. Newborn \& Infant Nursing, 13 (1), 9-22.

9. Znamenska, T.K., Nikulina, L.I., Rudenko, N.H., Vorobyova, O.V. (2017). Analiz roboty perynatalnykh tsentriv u vykhodzuvanni peredchasno narodzenykh ditei v Ukraini [Analysis of the work of perinatal centers in the emergence of premature births in Ukraine]. Neonatolohiia, khirurhiia, perynatalna medytsyna Neonatology, Surgery, Perinatal Medicine, 2 (24), 5-7. 